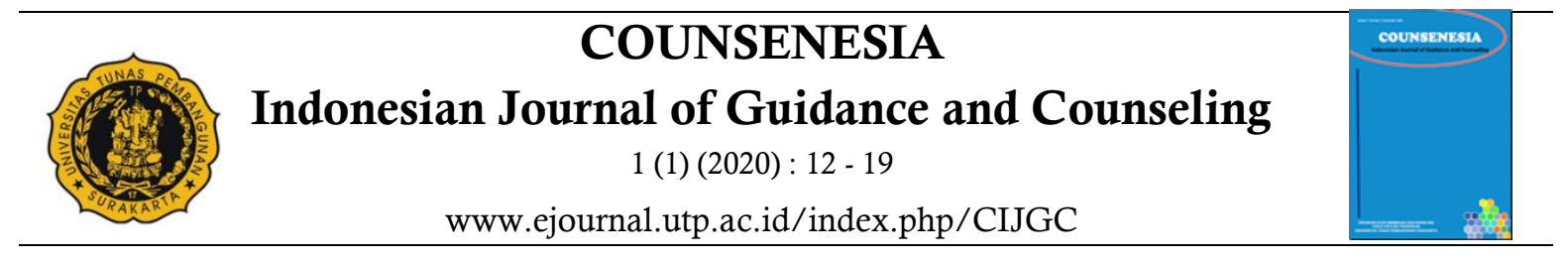

\title{
URGENSI KOMPETENSI MULTIKULTURAL DARI KONSELOR SEBAGAI SARANA MEMBANGUN INTEGRITAS BANGSA
}

\author{
Nurul Azizah \\ nurulazizahnr25@gmail.com \\ Universitas Borneo Tarakan

\begin{tabular}{l}
\hline Info Artikel \\
\hline Riwayat Artikel \\
Diterima: \\
Juni 2020 \\
Disetujui: \\
Juni 2020 \\
Publikasi: \\
Juni 2020 \\
\hline
\end{tabular} \\ DOI :

\begin{abstract}
Abstrak
Indonesia is a country with cultural diversity. This diversity is wealth and is a challenge for Indonesia because it can create opportunities but on the other hand it car also trigger conflict. Differences in cultural background will affect perceptions, ways of thinking, and language used so that it creates various obstacles. Counselors have c role to be able to channel their competence across cultures. Through awareness $\mathrm{o}$ : cultural values, knowledge and understanding of culture, and cultural skills possessec by the counselor. This multicultural competency can be a bridge for counselors tc provide assistance optimally. An important integrity value is to be instilled in the youn generation as the nation's successor. Integrity will build the young generation to have c leadership spirit, be responsible for themselves, family, and society, and form a good honest, committed, humble and authoritative personality for the younger generation anc prevent anarchic and radical actions, Someone who has self integrity will give a bi६ influence and bring benefits in life. This forms a superior young generation. With propes handling, it will help develop and improve the quality of the young generation.
\end{abstract}

Keywords: Multicultural Competency Of Counselor, Integrity

\begin{abstract}
ABSTRAK
Indonesia merupakan negara dengan keragaman budaya. Keragaman in merupakan kekayaan dan menjadi tantangan bagi Indonesia karena dapat menciptakar peluang tetapi di sisi lain juga dapat memicu konflik. Perbedaan latar belakang budayc akan mempengaruhi persepsi, cara berpikir, dan bahasa yang digunakan sehingga menimbulkan berbagai hambatan. Konselor memiliki peran untuk dapat menyalurkar kompetensinya dalam lintas budaya. Melalui kesadaran akan nilai-nilai budaya pengetahuan dan pemahaman akan budaya, serta keterampilan budaya yang dimilik oleh konselor. Kompetensi multikultural ini dapat menjadi jembatan bagi konselos untuk memberikan bantuan secara optimal. Nilai integritas penting untuk ditanamkar pada generasi muda sebagai penerus bangsa. Integritas akan membangun generasi mudc untuk memiliki jiwa kepemimpinan, bertanggung jawab pada diri sendiri, keluarga, dar masyarakat, serta membentuk kepribadian yang baik, jujur, komitmen, rendah hati, dar berwibawa pada diri generasi muda serta mencegah dari tindakan-tindakan yang anarkis dan radikal. Seseorang yang memiliki integritas diri akan memberikan pengaruh yan€ besar dan membawa manfaat dalam kehidupan. Hal ini membentuk generasi muda yanє unggul. Dengan adanya penanganan yang tepat maka akan membantu mengembangkar dan meningkatkan kualitas para generasi muda.
\end{abstract}

Kata kunci: Kompetensi Konselor Multikultural, Integritas 


\section{PENDAHULUAN}

Indonesia merupakan Negara multikultural karena terdiri dari berbagai macam budaya yang beraneka ragam. Keragaman ini merupakan kekayaan dan menjadi tantangan bagi Indonesia. Ini semua merupakan peluang yang besar namun juga dapat memicu konflik. Banyaknya konflik yang terjadi akhir-akhir ini. Integritas sedang tergadaikan, berbagai macam orang yang diuji namun gagal karena jabatan dan harta. Hal ini memperlihatkan pentingnya integritas ada pada diri seseorang, untuk ia menjalani kehidupannya.

Dunia pendidikan memiliki peran yang sangat potensial untuk mengarahkan siswa kearah yang benar dan tepat. Kondisi psikologis siswa merupakan masa yang rentan dan sangat sensitif terhadap pengaruh teman-teman dan lingkungan sekitarnya. Perlunya ditanamkan nilai integritas pada diri siswa karena pada masa sekolah remaja atau siswa sedang mencari dan mengalami pembentukan jati diri dan karakter dirinya. Integritas akan membangun generasi muda untuk memiliki jiwa kepemimpinan, bertanggung jawab pada diri sendiri, keluarga, dan masyarakat, serta membentuk kepribadian yang baik, jujur, komitmen, rendah hati, dan berwibawa pada diri generasi muda serta mencegah dari tindakan-tindakan yang buruk, anarkis dan radikal. Seseorang yang memiliki integritas diri akan membawa manfaat dalam kehidupan dan akan menciptakan generasi muda yang unggul. Dengan adanya penanganan yang tepat maka akan membantu mengembangkan dan meningkatkan kualitas para generasi muda.

Layanan bimbingan dan konseling adalah salah satu langkah nyata dalam dunia pendidikan yang sangat dibutuhkan. Dalam dunia pendidikan tentunya terdiri dari siswasiswa yang berasal dari budaya yang berbeda-beda. Perbedaan latar belakang budaya ini akan mempengaruhi persepsi, cara berpikir, dan bahasa yang digunakan siswa dalam kehariannya. Hal ini juga seringkali menimbulkan berbagai hambatan.

Penelitian yang dilakukan oleh Triningtyas (2016) menyatakan bahwa keefektifan konseling dipengaruhi oleh bebrapa faktor, salah satunya adalah hubungan yang terjalin antara konselor dan konseli berjalan dengan harmonis dan selaras serta saling mengerti. Dengan keragaman budaya ini seringkali muncul permasalahan dan hambatan. Disinilah sangat dibutuhkan layanan bimbingan dan konseling melalui konsep multibudaya dalam memberikan informasi, pengetahuan dan wawasan pada siswa serta membantu dalam membentuk pribadi yang mampu untuk saling menghargai dan menghormati dalam segala perbedaan yang ada. Sehingga siswa terhindar dari kesalahan pemahaman terhadap perbedaan yang ada. Konselor memiliki peran untuk dapat menyalurkan kompetensinya dalam lintas budaya. Melalui kesadaran akan nilai-nilai budaya, pengetahuan dan pemahaman akan budaya, serta keterampilan budaya yang dimiliki oleh konselor. Kompetensi multikultural ini dapat menjadi jembatan bagi konselor untuk memberikan bantuan secara optimal.

Kemdikbud (2017) dalam rangka melakukan revolusi karakter penerus bangsa dilakukan gerakan Penguatan Pendidikan Karakter (PPK) yang dikeluarkan sejak 2016. Ada lima karakter utama yang menjadi prioritas dalam gerakan PPK ini yaitu religious, nasionalisme, integritas, kemandirian dan gotong royong. Kelima karakter ini saling berinteraksi satu sama lainnya membentuk keutuhan pribadi. Pada nilai yang pertama yaitu nilai karakter religious, nilai yang mencerminkan keimanan kepada Tuhan yang Maha Esa dengan melaksanakan ajaran agama, bersikap toleran terhadap agama lain, dan saling menghargai. Yang kedua nilai nasionalisme yaitu bagaimana cara berpikir, bertindak itu memperlihatkan bentuk apresiasi budaya bangsanya, taat hukum, setia, disiplin, cinta tanah air dan lain sebagainya. Yang ketiga yaitu nilai integritas, nilai yang 
mendasari seseorang dapat dipercaya dalam ucapan, tindakan, komitmen pada nilai-nilai kemanusiaan dan moral serta dapat dijadikan sebagai teladan. Yang keempat yaitu nilai mandiri, merupakan sikap seseorang yang memiliki daya juang dan tidak bergantung pada orang lain. Dan yang terakhir nilai karakter kelima yaitu nilai gotong royong, mencerminkan seseorang yang dapat bekerja sama, tolong menolong, memiliki rasa solidaritas, dan bersikap empati pada sesama.

Dalam penelitian Soegiharto (2014) isu yang sejak lama menjadi isu negatif yaitu integritas pada aparatur pemerintah, kualitas pelayanan yang mengecewakan dan tingginya tingkat korupsi menjadi bahan pembicaraan selama ini. jika seseorang memiliki integritas maka ia akan bisa membedakan mana yang benar dan mana yang salah karena adanya peran hati nurani dan moral dalam setiap ucapan dan tindakan. Hak ini sangat dibutuhkan oleh siswa, konselor dan para pendidik harus melakukan kolaborasi untuk menanamkan nilai-nilai tersebut hingga menumbuhkan dan mengembangkan karakter positif pada diri siswa.

Dalam pembahasan ini menekankan pada karakter integritas yang saat ini sangat perlu untuk ditanamkan pada diri siswa sebagai generasi penerus bangsa. Pendidikan diharapakan dapat menjadi dasar yang kuat bagi penanaman integritas siswa. Dan saat inilah peran dari layanan bimbingan dan konseling untuk mencurahkan segala kemampuan dan kompetensi yang dimilikinya. Karena Indonesia memiliki keragaman budaya dan menyebabkan siswa-siswi berasal dari latar belakang budaya berbeda, maka sangat dibutuhkan kompetensi multikultural pada diri konselor untuk menanamkan dan membangun pendidikan dengan karakter integritas.

\section{PEMBAHASAN}

Siswa merupakan harapan bangsa, generasi penerus yang diharapkan mampu menjadikan Indonesia menjadi lebih baik. Siswa mempunyai peran penting dalam banyak hal untuk nantinya membawa Indonesia menuju perbaikan. Pentingnya pemahaman mengenai integritas pada siswa sehingga siswa memiliki karakter dan kualitas diri yang baik. Berbeda dengan saat ini banyaknya siswa yang tidak jujur, mencontek saat ujian, dan lain sebaginya. Hal ini jika terus diabaikan maka akan berdampak pada masa depannya dan bisa saja berujung pada perilaku korupsi. Saat ini korupsi sedang merajalela. Korupsi perlu segera ditangani dan untuk mencegah siswa dikemudian hari berbuat hal yang serupa, maka sangat diperlukan integritas pada diri siswa.

Sihombing (2018) menyatakan bahwa integritas adalah perilaku yang dipelajari. Integritas mewakili kualitas perilaku individu yang konsisten dan mengintegrasikan apa yang mereka katakan dengan apa yang mereka lakukan. Itu mencerminkan karakter positif yang didasarkan pada norma dan etika. Keluarga adalah teladan utama untuk integritas pembelajaran dan banyak bentuk media komunikasi seperti televisi dan internet lebih fokus pada korupsi yang melibatkan contoh-contoh orang yang bertindak tanpa integritas.

Bieliauskaite (2014) menjelaskan bahwa integritas adalah kepatuhan terhadap instruksi hati nurani yang benar, pendidikan memiliki tugas untuk mengembangkan integritas pada diri siswa dengan memberikan pemahaman dan pengetahuan untuk dapat mengembangkan wawasan dan kemampuan siswa sehingga dapat mengevaluasi kebenaran atau kesalahan motif (objek). Maak dalam Bieliauskaite (2014) mengatakan bahwa seseorang memiliki integritas jika ia bertindak sesuai dengan prinsip-prinsip moral yang penting serta melakukannya dengan cara yang koheren dan konsisten setiap harinya. 
Penelitian yang dilakukan Devine, C.A.\& Chin, E. D (2018) mendefinisikan atribut untuk integritas mahasiswa keperawatan adalah kejujuran, perilaku etis dan profesionalisme sebagai atribut integritas yang menentukan. Sedangkan dalam penelitian Redjeki, D. P. S \& Heridiansyah, J (2013) menyatakan pentingnya memahami bagaimana konsep dasar integritas, yang mana integritas merupakan gambaran keseluruhan pada pribadi sesorang dan akan mengarahkan pada perilakunya. Adapun seseorang yang memiliki integritas akan berperilaku sebagai berikut: a) Jujur; b) Konsisten (sesuai antara apa yang diucapkan dan apa yang dilakukan; c) Memiliki etika dan mematuhi peraturan; d) Komitmen dengan prinsip-prinsip yang benar; e) Bertanggung jawab; f) memiliki kualitas umtuk dihormati; g) patuh pada prinsip-prinsip moral; h) Adil dalam membedakan benar dan salah.

\section{KOMPETENSI MULTIKULTURAL KONSELOR}

Sue \& Sue (2008) menjelaskan definisi multikulturalisme merupakan perpaduan antara perbedaan gender, ras, status dan tempat tinggal pada masing-masing orang akan menghasilkan pengalaman dan karakter. D'Andrea dan Daniels (dalam Ratts \& Pedersen, 2014) menjelaskan bahwa konseling multikultural adalah terjadinya interaksi antara seorang yang professional dengan klien yang memiliki latar belakang budaya yang berbeda dan bertujuan untuk mengembangkan kognitif, emosional, psikologis, dan spiritual klien. Sedangkan Ratts \& Pedersen (2014) mengungkapkan bahwa konseling multikultural merupakan perpaduan beberapa budaya yang mempengaruhi dan membentuk pandangan dunia, perilaku, dan pengalaman hidup kita.

Kompetensi budaya adalah kemampuan untuk terlibat langsung dalam usaha menciptakan kondisi yang dapat memaksimalkan pengembangan optimal pada diri konseli. Kompetensi konseling multikultural didefinisikan sebagai kemampuan yang dimiliki konselor atas kesadaran budaya, pengetahuan, dan keterampilan yang dibutuhkan dan dimanfaatkan secara efektif dalam kemampuan berkomunikasi dan berinteraksi yang berasal dari latar belakang budaya yang berbeda (D. W. Sue \& Torino dalam Sue \& Sue, 2008).

Penelitian yang dilakukan Mustaffa, Sharif. Dkk (2013) menunjukkan bahwa untuk mengembangkan layanan konseling agar menjadi efektif konselor harus memiliki kompetensi keterampilan dan adanya pengembangan pada pribadinya serta mempunyai kecerdasan secara emosional. Hal ini menjelaskan bahwa konselor tidak cukup hanya dengan memiliki kecerdasan intelektual saja, tetapi juga memiliki kecerdasan secara emosional.

Masturi (2015) menyatakan bahwa seberapapun besar dan kuatnya nilai-nilai budaya yang dianut oleh seorang konselor, ia tidak boleh mengungkung dirinya pada kebenaran budanyanya karena cenderung akan resisten pada kebenaran budaya lain dari konseli. Penelitian Nugraha (2018) menyatakan bahwa untuk menciptakan hubungan yang efektif, efisien, harmonis dan selaras anatara konselor dan konseli adalah dengan memiliki kecerdasan budaya selama pemberian layanan sehingga dapat tercapai sesuai dengan tujuan konseling yang dikehendaki. Hal ini akan menciptakan kenyamanan selama proses layanan, terselesaikannya masalah konseli, dan durasi pada saat layanan lebih efisien.

Konseling multikultural sangat diperlukan di sekolah khususnya untuk para siswa, konselor memberikan bantuan dan pertolongan dengan melibatkan kognitif, emosional, psikologis dan spiritual dari siswa yang berasal dari latar belakang budaya yang berbedabeda. Kompetensi multikultural sangat penting pada diri seorang konselor, karena dengan kemampuan tersebut konselor dapat memiliki kesadaran mengenai nilai-nilai dan bias 
yang ada, memiliki pengetahuan dan wawasan yang luas sehingga dapat memahami pandangan dunia dari sudut pandang konseli yang berlatar belakang budaya berbeda, dan terakhir memiliki keterampilan dalam mengembangkan teknik intervensi yang tepat.

Berdasarkan hasil Kassan, Anusha \& Sinacore, A. L. (2016) menunjukkan bahwa kompetensi yang penting saat mengahadapi konseli remaja perempuan adalah perlunya kesadaran, pengetahuan, keterampilan dan hubungan konseling multikultural. Konselor juga perlu memiliki kepekaan terhadap budaya dan mengetahui serta memahami cara pandang dan identitas budaya dari konseli sehingga konselor akan lebih memahami remaja perempuan dan menghasilkan konseling yang lebih baik.

\section{URGENSI KOMPETENSI MULTIKULTURAL KONSELOR DALAM PEMBENTUKAN INTEGRITAS}

Pertemuan antara individu yang satu dengan individu lainnya akan mempertemukan juga pada karakter budaya yang berbeda, hal ini menyebabkan adanya permasalahan dalam benturan budaya. Hal ini menuntut untuk lebih memahami satu dengan yang lainnya dan sadar akan keberagaman budaya, sehingga akan menumbuhkan kemampuan dalam adaptasi, membangun hubungan baik dengan orang lain, dan dapat memecahkan konflik yang terjadi akibat perbedaan budaya.

Konseling lintas budaya melibatkan adanya hubungan dan interaksi antara konselor dan konseli yang memiliki latar belang budaya yang berbeda, hal ini menyebabkan cenderung dalam prosesnya menimbulkan bias-bias budaya sehingga kurang efektifnya layanan konseling tersebut. Sejalan dengan penelitian Elizar (2018) yang menyatakan bahwa perbedaan budaya antara konselor dan klien menyebabkan adanya perbedaan persepsi, dan ini merupakan salah satu faktor hambatan dalam proses konseling. Fenomena ini mendorong konselor untuk memiliki kompetensi multikultural sehingga bisa memberikan layanan yang efektif pada siswa.

Saat terjadinya proses konseling, konselor perlu memiliki kepekaan budaya dan menyadari bahwa setiap konseli itu memiliki karakteristik yang unik sehingga dapat mengerti dan memahami serta membantu konseli sesuai dengan budaya konseli tersebut. Memperhatikan latar belakang budaya sangat penting karena faktor budaya memiliki kontribusi dalam pelaksanaan konseling. Sejalan dengan penelitian Annajih, M. Z. H., Lorantina, K., \& Ilmiyana, H. (2017) menjelaskan bahwa dengan adanya praktik konseling dengan konsep multibudaya akan menjadi sebuah tawaran konseptual dalam pendidikan khususnya untuk membantu para siswa dalam membentuk pribadi yang multibudaya. Melihat pentingnya hal ini maka sangat dibutuhkan konselor yang memiliki kompetensi multikultural. Dengan adanya kompetensi multikultural pada diri konselor akan mengoptimalkan pemberian bimbingan dan bantuan pada siswa.

Diniaty (2018) menyatakan konselor perlu waspada adanya miskonsepsi nilai budaya antara konselor dengan konseli. Konselor perlu menyadari bahwa teknik intervensi dalam konseling tidak dapat digeneralisasikan pada semua konseli yang berasal dari latar belakang budaya yang berbeda-beda. Jika konselor tidak memiliki kemampuan untuk menentukan teknik yang tepat sesuai dengan latar belakang konseli maka akan menimbulkan beberapa hambatan. Seperti pada penelitian yang dilakukan oleh Mak, A. S \& Shaw, T. L (2015) yang mengungkapkan bahwa terdapat beberapa hambatan jika seorang konselor tidak memiliki kompetensi budaya seperti interaksi sosial antar budaya akan semakin menantang dan hubungan terapeutik antar budaya. Ketika dalam proses pemberian layanan seorang konselor memiliki kompetensi multikultural tersebut maka 
akan tercapai keberhasilan dari layanan psikologis dan konseling tersebut dalam masyarakat multikultural.

Kompetensi multikultural sangat penting pada diri seorang konselor, karena dengan kemampuan tersebut konselor dapat memiliki kesadaran mengenai nilai-nilai dan bias yang ada, memiliki pengetahuan dan wawasan yang luas sehingga dapat memahami pandangan dunia dari sudut pandang konseli yang berlatar belakang budaya berbeda, dan terakhir memiliki keterampilan dalam mengembangkan teknik intervensi yang tepat. Konselor yang memiliki kepekaan terhadap budaya dan mengetahui serta memahami bagaimana cara pandang dan identitas budaya dari konseli dapat lebih memahami posisi dari konseli. Dengan adanya kompetensi multikultural pada diri konselor akan mengoptimalkan dan mengefektikan proses layanan.

Menurut Th. E. Becker dalam Bieliauskaite (2014) adanya perbedaan antara keinginan pribadi dan nilai-nilai moral akan menyebabkan ketiadaan integritas. Konselor hendaknya memberikan pemahaman nilai-nilai mengenai integritas dan pentingnya hal tersebut bagi siswa dalam proses pembelajaran dan perkembangan moral siswa. Penelitian Redjeki, D. P. S \& Heridiansyah, J (2013) menyatakan pentingnya memahami bagaimana konsep dasar integritas, yang mana integritas merupakan gambaran keseluruhan pada pribadi sesorang dan akan mengarahkan pada perilakunya.

Dengan pemberian informasi yang benar dan cara yang tepat maka akan lebih mudah untuk diterima oleh siswa. Sehingga nilai-nilai integritas dapat diterapkan pada diri siswa masing-masing. Konselor akan lebih memahami dan mengerti bagaimana cara untuk menyampaikan ataupun tujuan dilakukannya proses layanan. Dengan adanya kompetensi multikultural maka apa yang dimaksud oleh siswa atau konselor akan tersampaikan dengan benar. Sehingga layanan berjalan dengan optimal, dapat mencegah siswa dari perilaku yang tercela, dan dapat membentuk kepribadiannya dengan baik serta berintegritas. Pendidikan saat ini tidak hanya untuk meningkatkan intelektual saja, namun di generasi saat ini konselor harus berusaha untuk membantu dunia pendidikan ini dengan melakukan usaha untuk meningkatkan dan mengembangkan emosional dan moral siswa.

\section{Simpulan}

Dunia pendidikan memiliki peran yang sangat potensial untuk mengarahkan siswa kearah yang benar dan tepat. Kondisi psikologis siswa merupakan masa yang rentan dan sangat sensitif terhadap pengaruh teman-teman dan lingkungan sekitarnya. Perlunya ditanamkan nilai integritas pada diri siswa karena pada masa sekolah remaja atau siswa sedang mencari dan mengalami pembentukan jati diri dan karakter dirinya. Dalam dunia pendidikan tentunya terdiri dari siswa-siswa yang berasal dari budaya yang berbeda-beda. Perbedaan latar belakang budaya ini akan mempengaruhi persepsi, cara berpikir, dan bahasa yang digunakan siswa dalam kehariannya. Konselor memiliki peran untuk dapat menyalurkan kompetensinya dalam lintas budaya. Melalui kesadaran akan nilai-nilai budaya, pengetahuan dan pemahaman akan budaya, serta keterampilan budaya yang dimiliki oleh konselor. Kepekaan yang tajam pada konselor akan membuatnya lebih memahami dan menghargai bias budaya antara konselor dan konseli dan diharapkan akan membantu konseli secara optimal.

Konselor harus memiliki kemampuan untuk menentukan teknik intervensi yang tepat dalam pemberian layanan pada konseli berdasarkan latar belakang budaya yang berbeda-beda sehingga dapat menghasilkan layanan yang optimal dan efektif. Dengan pemberian informasi yang benar dan cara yang tepat maka akan lebih mudah untuk diterima oleh siswa. Sehingga nilai-nilai integritas dapat diterapkan pada diri siswa 
masing-masing. Konselor akan lebih memahami dan mengerti bagaimana cara untuk menyampaikan ataupun tujuan dilakukannya proses layanan. Dengan adanya kompetensi multikultural maka apa yang dimaksud oleh siswa atau konselor akan tersampaikan dengan benar. Sehingga layanan berjalan dengan optimal, dapat mencegah siswa dari perilaku yang tercela, dan dapat membentuk kepribadiannya dengan baik serta berintegritas.

\section{DAFTAR PUSTAKA}

Annajih, M. Z. H., Lorantina, K., \& Ilmiyana, H. 2017. Konseling Multibudaya Dalam Penanggulangan Radikalisme Remaja. Prosiding Seminar Bimbingan dan Konseling. Vol. 1(1). hlm. 280-291

Bieliauskaite, Jolanta. 2014. On the way to professionalism the promotion of law students' academic integrity. Procedia Social and Behavioral Sciences. 116. 4229-4234. doi: 10.1016/j.sbspro.2014.01.922

Devine, C.A.\& Chin, E. D. 2018. Integrity in nursing students: A concept analysis. Nurse Education Today. 60. 133-138. doi.org/10.1016/j.nedt.2017.10.005

Diniaty, Amirah. 2018. Mewaspadai Miskonsepsi Nilai Budaya Dalam Pelaksanaan Konseling Individual. Educational Guidance and Counseling Development Jounal. Vol. 1(1). $6-15$

Elizar. 2018. Urgensi Konseling Multikultural Di Sekolah. Jurnal Elsa. Volume 16(2). $13-22$

https://www.kemdikbud.go.id/main/blog/2017/07/penguatan-pendidikan-karakter-jadipintu-masuk-pembenahan-pendidikan-nasional (diakses jumat 30 November 2018)

Kassan, Anusha \& Sinacore, A. L. 2016. Multicultural Counselling Competencies with Female Adolescents: A Retrospective Qualitative Investigation of Client Experiences. Canadian Journal of Counselling and Psychotherapy. Vol. 50(4). Pages 402-420

Mak, A. S \& Shaw, T. L. 2015. Perceptions of Intercultural Social Challenges: Towards Culturally Competent Counselling Practice. Journal Of Psychologists and Counsellors in School. Vol 25. pp 183-199. doi 10.1017/jgc.2015.13

Masturi. 2015. Counselor Encapsulation: Sebuah Tantangan Dalam Pelayanan Konseling Lintas Budaya. Jurnal Konseling GUSJIGANG. Vol. 1(2). ISSN 2460-1187

Mustaffa, Sharif. Dkk. 2013. Emotional intelligence, skills competency and personal development among counseling teachers. Procedia - Social and Behavioral Sciences. 93, 2219 - 2223. doi: 10.1016/j.sbspro.2013.10.191

Nugraha, Agung. 2018. Kecerdasan Budaya Dalam Proses Bantuan Penyelesaian Masalah. Journal of Innovative Counseling: Theory, Practice \& Research. 2 (1), pp. 14-19

Ratts, M, J. \& Pedersen, P, B. 2014. Counseling for Multiculturalism and Social Justice. Alexandria, VA: American Counseling Association

Redjeki, D. P. S \& Heridiansyah, J. 2013. Memahami Sebuah Konsep Integritas. Jurnal Stie Semarang. Vol 5(3) ISSN : 2252-7826

Sihombing, Sabrina O. 2018. Youth perceptions toward corruption and integrity: Indonesian context. Kasetsart Journal of Social Sciences. 39 (299-304). doi.org/10.1016/j.kjss.2018.03.004

Soegiharto, Rachmat. 2014. Membangun Integritas Widyaiswara. Jurnal Lingkar Wiyaiswara. Edisi 1(4). Hal 92-103. ISSN : 2355-4118 
Sue, Derald Wing \& Sue, David. 2008. Counseling the Culturally Diverse Theory and Practice. Wiley: John Wiley \& Sons, Inc.

Triningtyas, D. A. 2016. The Roles Of Counselor In Multicultural Community. Proceedings International Seminar FoE (Faculty of Education). Vol. 1. Hal 338344 